\title{
Irrigando desertos: educação e imaginação em C.S. Lewis
}

\author{
Irrigating deserts: education and imagination \\ in C.S. Lewis
}

\section{Irrigación de desiertos: educación e imaginación en C.S. Lewis}

\section{Gabriele Greggersen}

\begin{abstract}
RESUMO
O objetivo do artigo, baseado no livro de C.S. Lewis, A Abolição do Homem, é compreender e discutir a importância da imaginação numa educação baseada no Tao. Perguntamo-nos em que situações e em que medida a educação se torna um deserto e como o uso da imaginação pode remediar essa situação? Após a compreensão e discussão dos aspectos essenciais do livro e de sua importância na educação, faremos algumas aplicações da filosofia educacional de $A$ Abolição do Homem à educação que se queira cristã. A questão central é: $\mathrm{O}$ que podemos aprender do homem imaginativo, C.S. Lewis, e essa obra em particular sobre educação, numa perspectiva cristã?
\end{abstract}

Palavras-chave: C.S. Lewis; imaginação; educação cristã.

\begin{abstract}
The aim of the paper, that is based on the book of C.S. Lewis, The Abolition of Man, is to realize and discuss the importance of imagination in an education based on the Tao. We are asking in which situations and in which measure education is becoming desertic and how can the use of imagination remediate that situation? After the understanding and discussion of the essential aspects of the book and of its importance to education, we will apply the philosophy of education of The Abolition of Man to an education which is Christian. The main question is: what can we learn from the imaginative man in C.S. Lewis and this particular work about education in a Christian perspective?

Keywords: C.S. Lewis; imagination, Christian Education.

\section{RESUMEN}

El propósito del artículo, basado en el libro de C.S. Lewis, La Abolición del Hombre, es comprender y discutir la importancia de la imaginación en una educación basada en el Tao. Nos preguntamos en qué situaciones y en qué medida la educación se convierte en un desierto y cómo el uso de la imaginación puede remediar esta situación. Después de comprender y discutir los aspectos esenciales del libro y su importancia en la educación, haremos algunas aplicaciones de la filosofía educativa de La Abolición del Hombre a la educación que quiere ser cristiana. La pregunta central es: ¿Qué podemos aprender del hombre imaginativo, C.S. Lewis, y de este trabajo en particular sobre educación, desde una perspectiva cristiana?

Palabras clave: C.S. Lewis; imaginación; educación cristiana.
\end{abstract}




\section{Introdução}

Neste artigo, vamos apresentar e debater as implicações do livro de C.S. Lewis, intitulado Abolição do Homem para a educação, particularmente a cristã. $\mathrm{Na}$ obra, ele fala que a humanidade está prestes a se autodestruir, principalmente, se ela continuar a avançar em certas tendências de pensamento que se manifestam em especial na educação. Lewis começa seu estudo, tratando de um livro didático de língua e literatura inglesa para crianças. E na exposição, ele vai argumentando e debatendo com os autores do livro, cujos nomes ele substitui por outros fictícios e o livro, chama de Green Book [Livro verde] por motivos éticos. Parafraseando a frase auge desse livro, ela diz que na educação, não importa "derrubar florestas", mas "irrigar desertos". Vamos tentar entender o que essa frase quer dizer a partir de uma metáfora.

Imagine-se perdido no meio de um deserto. Você está morrendo de sede e tem uma visão do famoso oásis. E você contempla aquela imagem. Muitos o advertiriam, dizendo: "não, essa imagem é pura ilusão", "ela é fruto do seu desejo, da sua sede, da sua psiqué que está tentando te enganar." Então, o homem ou mulher céticos dariam de ombros e caminhariam na direção oposta dela.

$\mathrm{Na}$ verdade, uma miragem, por mais distorcida que possa parecer, serve, sim, para alguma coisa. Ela pode ter alguma distorção ocasionada pelo seu desejo, mas ela é basicamente uma imagem objetiva, um fenômeno ótico e, portanto, ela é dotada de fundamento na realidade concreta. Ela é um fenômeno tão ótico, que se poderia tirar fotos dela, de tão real que é. Ela pode até aparecer distorcida, ou de cabeça para baixo, porque ela é resultante de reflexos, ou pode ser ampliada, como acontece no retroprojetor: a imagem que fica sobre o vidro é lançada para frente de forma ampliada. Hoje isso acontece de forma inteiramente digital com o uso do data-show. Considerando que ela pode ter fundamento real, para que ela pode servir? Muitas pessoas diriam: "Ela serve para motivar, para a pessoa ter esperança de acabar conseguindo achar sombra e água fresca.

No entanto, ela faz mais do que nos acalmar e servir de estímulo psicológico, ela mostra a direção, o rumo, o caminho que você deve seguir. Ali, naquela direção é que há esperança. Não é para cá, nem acolá, nem para trás. É para frente, em direção a ela, que você deve caminhar. E muitas vezes ela não está bem ali onde você pensa que ela está. Comumente, está mais longe do que você está pensando e enxergando.

É o mesmo que acontece quando você anda no asfalto quente, debaixo de muito sol, e parece que ele está brilhoso, cintilante. E quando vem um caminhão, parece que ele está em cima devocê, mas, na verdade, ele demora 
a chegar. O mesmo fenômeno acontece quando você olha para uma ilha num dia muito quente, e pensa que ela está a seu alcance, se der umas boas braçadas. Então, você entra em um barco e parece que o traslado demora muito mais do que o esperado.

O sonho e a utopia (lembrando que u-topos, significa "não lugar": não apenas no sentido do inexistente, mas de algo que existe, mas está projetado em um outro lugar) têm a mesma estrutura da miragem do deserto: Eles parecem ao alcance da mão, mas na verdade estão mais longe. Eles nunca se concretizam exatamente da forma como aparecem. E esse fenômeno vai além da percepção, abarcando domínios da realidade que transcendem os nossos sentidos e a nossa razão ou capacidade de explicação ou compreensão Com esse tipo de experiência visionária se alcança o que Rudolf Otto (2007) chamou de "numinoso", que faz parte de sua ideia do sagrado.

O numinoso é para onde somos elevados, quando contemplamos a natureza ou uma obra de arte, como uma pintura ou escultura, por exemplo, ou uma poesia, ou uma música. A arte não é algo apenas agradável e encantador, mas grandioso, magnífico, majestoso, esplêndido, extraordinário, muito nobre, enfim, algo poderoso, que evoca imagens. E o numinoso é também um estado de graça, um estado de elevação e inspiração, e, no sentido religioso, espiritual, algo que se abre ao transcendente. Ele nos transporta para além da realidade, para algo de essência mais concreta do que a realidade dos fatos.

Mas o livro didático dos autores, mencionado por Lewis, se refere ao sublime como um simples sentimento subjetivo. Mesmo se admitirmos que é um sentimento, trata-se de um tipo especial, que está totalmente fora e obliterado nos livros didáticos em geral e que não é de ordem apenas subjetiva, como os livros didáticos nos querem fazer crer.

A própria natureza, se a considerarmos como obra de arte do Criador, nos pode transportar para um estado ou condição espiritual destas, em que nos espantamos e começamos, portanto, a filosofar e ir além do visto, superando-o.

Em educação, a ideia de "projeto" ou até mais especificamente de "projeto pedagógico" tem relação com o sonho, a utopia e a arte, já que tem essa função de "projetar" um sonho educacional para frente, que envolve a superação de certo estado de coisas. Ele dá ao educador e a todos os envolvidos no processo, uma sensação de elevação, e assim provoca a motivação e o rumo certo a seguir, de que tanto se carece no cotidiano escolar desnorteado de hoje.

Também a pintura, e a arte em geral, sugere o poder que a imagem tem de não apenas deslumbrar, de mostrar esteticamente o que é bonito, mas 
também de passar uma paz, uma calma, um refrigério que parece vir "de outro mundo". Trata-se daquele sentimento que uma criança tem ao estar junto de sua mãe, perto daquela que a nutre e lhe presta toda a assistência e cuidado. Trata-se de um sentimento subjetivo, sim, mas que tem base numa realidade concreta que transcende o mundo restrito do bebê.

E, particularmente no campo da educação, que é um campo das mediações, mas também das projeções e superações, a imagem e a imaginação, envolvidos por exemplo nas histórias e sua contação e no lúdico em geral, têm um poder e uma eficiência especial.

A educação necessita das imagens como ferramentas, e mais, como interfaces, como meios para alcançar determinados fins. Assim, o uso da imagem e apelo para a imaginação é um dos meios mais primorosos para se veicular a educação. Vamos detalhar essa ideia no que segue.

\section{A situação "desértica" da educação}

E por que a educação estaria no deserto, como sugere Lewis com a sua frase? Realmente, hoje, mais do que na época de Lewis, a educação está desértica. E eu a chamei aqui de "situação desértica da educação", justamente porque o que mais se vê é a derrubada de florestas. Derrubada da criatividade, pela imposição de uma agenda rígida de conteúdos que serão cobrados nas várias provas que o aluno tem que enfrentar em sua curta existência. Derrubada de educadores, pela sua situação financeira deplorável e falta de valorização de seu trabalho, além da sobrecarga, pela qual eles são transformados em "dadores" de aula. Derrubada de aprendizes, que são substituídos por alunos insatisfeitos que só fazem o que (e porque) são obrigados a fazer. Derrubada de ensinamentos com uma moral clara em favor de relativismos, tornando as aulas unilaterais e impositivas, que seguem filosofias baratas e lugares comuns. Estamos nos referindo ao que Paulo Freire chamava de "“educação' bancária”, do professor que deposita o "cheque" do conhecimento e vai embora, sem ter nenhuma interação ou dar satisfações ao aluno. Professores e alunos sem rumo. Aulas sobrecarregadas de informações e abstrações, desprovidas de gosto e de sentido. Grassa o racionalismo, em que o que importa são programas carregados de informações e conteúdos, muitas vezes inúteis e aceitos sem crítica e sem reflexão. Professores e alunos céticos que pensam que todo e qualquer ideia de transformação do espaço escolar, toda iniciativa, pode até ser motivadora e bela, mas não repousa numa realidade: que não passa de visão subjetiva ou formal, sem realidade concreta ou implicações na prática. 
A situação da educação é desértica, porque parece estar morta de tão fragmentária, porque teoria e a prática não se articulam, muito menos entram em reação química para formar realidades novas. Nela deparamos com professores e alunos céticos que pensam que todo e qualquer ideia de transformação do espaço escolar, toda iniciativa, pode até ser motivadora e bela, mas não repousa numa realidade: que não passa de uma visão gerada pela subjetividade, um idealismo sem fundamento numa realidade concreta ou implicações na prática.

Mas o que é mais precisamente um "projeto pedagógico". Elaborar projetos é o que faz um arquiteto, um engenheiro, quando projeta, forja a sua casa. Da mesma forma, o educador tem de bolar, maquinar, forjar aquilo em que quer formar o seu aluno, mas não de forma passiva, como se molda uma massa, mas na interação ativa entre o projetor e seu sujeito-objeto.

A aprendizagem acontece de forma contrária à fragmentação, quando há uma sinapse (à imagem do que acontece com os neurônios no cérebro) ou articulação e interação entre as coisas e as pessoas, que lhes dão sentido para além da mera informação e conteúdo.

\section{O livro: esse armazém de imagens}

Mas porque o uso do livro (e não me refiro ao livro didático) e da literatura, particularmente de contos imaginativos, também chamados de mitos, contos de fada e histórias fantásticas, é tão eficiente para pôr em prática o que estamos defendendo aqui. Ele está repleto de imagens, mesmo que não tenha ilustração nenhuma.

Destarte, todas as iniciativas de incentivo à leitura, seja através de contação de histórias, ou de distribuição de livros e e-books estão dentro do espírito lewisiano, principalmente no que diz respeito aos clássicos. Aliás, ele e seu amigo, J.R.R. Tolkien são mencionados no livro de Ana Maria Machado: Como e Por que ler os Clássicos Universais. (2002), que eu recomendo como leitura obrigatória para educadores comprometidos com a sua profissão e com um mundo melhor.

Mesmo os livros teóricos, filosóficos, pelo menos os bons livros, usam a metáfora, a analogia com muita frequência, que é o caso do livro que estamos focando aqui, A Abolição do Homem. Os grupos de discussão de Lewis na internet o sugerem como um dos primeiros livros a serem lidos da obra do autor. Claro que as Crônicas de Nárnia vêm antes. Elas representam aquele trampolim para se mergulhar mais fundo na teologia de C.S. Lewis. Mas Abolição vem logo em seguida com alimento sólido. 


\section{A abolição do homem}

A Abolição do Homem é um livro sobre educação, que resultou de três palestras dadas em 1943, portanto, antes do fim da Guerra, na Durkham University, voltadas para professores de ensino superior. Trata-se de uma crítica a um "livro verde", ou didático, ${ }^{1}$ que é The Control of Language: $A$ critical approach to reading and writing $[O$ Controle da Linguagem: uma abordagem critica da leitura $e$ da escrita], de Alex King e Martin Ketley, publicado em 1939. ${ }^{2}$

O livro está contextualizado na fase histórica de formação do nazismo e de transição na educação: "a educação antiga era uma espécie de propagação - homens transmitindo a humanidade para outros homens; a nova é apenas propaganda" (LEWIS, 2017a, p. 21). Então ele já faz a crítica da falta de educação clássica nas escolas, da literatura clássica, dos grandes pensadores dos grandes escritores. E, no lugar disso, oferece-se uma educação cheia de propaganda, cheia de consumismo e materialismo.

E Lewis introduz a temática do sublime ou do sentido estético, particularmente refletido na natureza, através de um riacho com uma queda d'agua, que aparece no livro verde. Enquanto o livro didático exalta a emoção subjetiva que se tem apreciando aquele cenário, a educação que Lewis quer promover é objetiva, ou seja, fundada na realidade. Ela não fica analisando o sublime em si, ou o sentimento que ele provoca, mas a realidade da cachoeira e sua beleza. Uma educação que olha para a imagem, tentando descobrir, não, que reações internas que ela provoca, mas a que outra coisa ela remete, que outra coisa real e objetiva ela lembra. Ele discute até que ponto esse sentimento de elevação que a natureza (ou a arte) provoca é algo puramente subjetivo, e defende que ele tem fundamento no real. Essa ideia é fundamental também para a sua filosofia (ou antropologia filosófica) e para a sua teologia. Será que as coisas que nós vemos são puramente subjetivas? Ou será que têm fundamento numa realidade externa, como aquela imagem no deserto?

\section{Visão objetiva e subjetiva}

Qual a diferença entre uma visão subjetiva e uma visão objetiva da realidade? Se todas as percepções e até sentimentos fossem subjetivos (é claro que muitos são), eles seriam todos irracionais.

\footnotetext{
1 A estatísticas dizem que o livro didático é o livro mais vendido no Brasil. Enquanto, no exterior, os best-sellers são romances, ficções; no Brasil são os livros didáticos, que os alunos são obrigados a ler. Qual a consequência dessa política para o hábito da leitura no Brasil? Até que ponto essa prática não estraga o gosto saudável pela leitura, que se torna algo enfadonho ou chato?

2 Fonte: Disponível em: <http://www.lewisiana.nl/abolquotes/>. [Acesso 24 de junho de 2014].
} 
Então, restar-nos-iam duas alternativas: negá-los, recaindo no racionalismo ou instituindo uma "polícia sentimental" e "mental" arbitrária, racionalista, totalitária (à moda do que acontece na obra 1984, de George Orwell); ou simplesmente afirmando que tudo é subjetivo, negando não as percepções e sentimentos, mas a realidade objetiva.

Mas a literatura não concorda nem com o racionalismo, nem com valores exclusivamente subjetivos. O próprio universo não concorda nem com o racionalismo, nem com subjetivismo. Tanto na literatura, quanto no universo, tudo remete a algo que é objetivo, que se encontra para lá da percepção humana.

A antropologia filosófica (lembrando que antropos, em grego, significa homem) de C. S. Lewis defende que a educação repousa precisamente na visão de ser humano implícita nela. Ou seja, a filosofia que ela constrói em torno do ser humano. A educação tem fins diferentes de acordo com a visão de realidade, mas principalmente de homem e da cosmologia que ela apresenta. E como essa concepção é interativa entre sujeito e objeto, e não apenas subjetiva, há um mérito nas coisas, é valoroso e válido conhecê-las. Enquanto uma visão subjetivista do ser humano não dá motivos concretos para se galgar o saber a respeito do mundo e do ser humano. ${ }^{3}$ Que benefício se tem de conhecer o que já se sabe, ou de se iludir com impressões dos sentidos, se o que vale é apenas a perspectiva interior (e ensimesmada)?

$\mathrm{Na}$ perspectiva lewisiana, que vou chamar de realista por falta de outro termo melhor, agindo sobre as coisas, o ser humano causa uma resposta e é capaz de interagir com o meio. Já, se tudo fosse subjetivo, se tudo fossem ilusões, não se teria como receber um feedback, tudo seria relativo. E muitos professores, que abraçam, quer seja o racionalismo, quer o subjetivismo, têm dificuldade de convencer o aluno de que é bom e valioso aprender coisas novas sobre o mundo e de provocar respostas nos seus alunos e reagir a elas. Se tudo são ilusões, não há nada na realidade a que responder, não há sinais a serem decifrados e não há critério nem mérito externo para aquilo que você faz ou deixa de fazer. Não há rumo a seguir e assim, a ação se torna desnorteada e aleatória, sem alcançar a tão esperada transformação que a educação deveria almejar e alcançar na vida real e cotidiana.

\section{Antropologia filosófica: ética}

O homem é composto de mente, corpo e alma; razão, vontade ou impulsos (instintos) e sentimentos. Se Deus é uma trindade e é nosso Criador,

\footnotetext{
3 É por isso que o projeto pedagógico prevê uma visão, uma missão e o perfil de egresso, ou seja, pergunta-se que aluno é esse que se pretende formar.
} 
à Sua imagem e semelhança, nós também somos uma trindade. ${ }^{4}$ A razão domina o homem visceral, por meio do peito, que em Lewis simboliza o elemento intermediário, mediador, responsável pelo equilíbrio através dos hábitos e da razão prática. Qualquer dos três elementos do ser humano pode ser exagerado, tornando-se destrutivo para a humanidade. Muitos "ismos" (racionalismo, tecnicismo, subjetivismo etc.) se dão pela desarmonia entre os membros da trindade humana.

A ética é precisamente a esfera que cuida do equilíbrio entre as coisas como veremos mais adiante. E a concepção lewisiana de "men without chests", "homens sem peito" ou "sem elemento intermediário" entre a cabeça e os membros inferiores, é a do ser humano a caminho de sua abolição ou extinção.

O termo que os chineses têm para ética ou moral é o Tao, citado por Lewis em $A$ Abolição... que significa o "Caminho Dourado do Meio". A ética básica deles diz simplesmente que se deve fazer "aos outros aquilo que gostaríamos que eles fizessem a nós", ou inversamente, "não fazer aos outros o que não gostaríamos que fizessem a nós". Ora, isso é precisamente o que diz a ética cristã. Daí que uma das teses centrais de $A$ abolição... seja a aproximação ou coincidência dos valores éticos das culturas de todos os tempos e lugares. ${ }^{5}$

Mas a cultura ocidental se esqueceu em grande parte dessa ética do bom senso, que une ocidentais e orientais embaixo do guarda-chuva da humanidade, criada à imagem e semelhança de Deus, criando vários Ersatz. (substitutos, em alemão) para ela.

Podemos alistar alguns substitutos para o Tao na cultura ocidental:

- Progressivismo - É a tese que diz que tudo o que é de última geração, é melhor e por isso o bem e o mal depende de sua novidade. Se o progressivismo (e evolucionismo) fosse verdadeiro, tudo que é mais novo seria sempre melhor, todas as coisas passadas, piores. Não haveria entropia, nem degradação. Ou seja, aqueles que acreditam muito que o ser humano está sempre se desenvolvendo e nunca degrada, vivem uma grande ilusão, por que nem tudo o que é mais antigo tem que ser superado, ou moralmente mau, ou medieval. ${ }^{6}$

4 Essa ideia é explorada em $A$ Mente do Criador, de Dorothy L. Sayers, que era amiga de Lewis e a quem dediquei a minha atual tese de doutorado. O livro foi prometido a sair publicado pela Editora É-Realizações.

5 Nos anexos do livro, Lewis inclui uma seleção de provérbios de todos os lugares e épocas que dizem praticamente as mesmas coisas sobre justiça, fidelidade e outros valores humanos universalizáveis, precisamente para provar a sua tese a respeito do Tao, ou seja, uma tábua de valores comuns a toda a humanidade.

6 Palavra mal compreendida, porque a Idade Média tem mais de mil anos de duração e é impossível que o ser humano estivesse vivendo no lado escuro da lua por um milhar de anos. E os historiadores descobrem cada vez mais coisas boas inventadas durante a Idade Média e sobre a importância que esse período teve para o progresso da humanidade. 
- Tecnicismo - Já para o tecnicismo, também denominado behaviorismo, ${ }^{7}$ que pode ser considerado uma variante do progressivismo, mas com características bem marcantes, os instintos são suficientes para dizer o que é bom e o que não é. O padrão normativo da conduta humana é o animal, são os instintos. Mas eles esquecem que a ética da natureza, o comportamento animal, por exemplo, é extremamente violento e agressivo. Se o ser humano pauta a sua ação, a sua conduta e a sua ética pelo comportamento instintivo, vai tender a ser agressivo. Irá seguir a lei do mais forte. Na verdade, os seres vivos submetem-se a uma guerra de instintos: a qual deles deveriam eles obedecer? Então, os behavioristas não têm critérios para dizer qual instinto você deve escolher como sendo o bom. Não há para eles critério do certo e do errado. E eles esquecem que ética é diferente de comportamento. Mesmo que se pregue o controle dos instintos pelo condicionamento, quem vai ditar qual o comportamento certo a ser condicionado? Lewis chama essa classe privilegiada da humanidade de "manipuladores", mas também podemos chamá-los de "nazistas".

- Utilitarismo- É a tese que diz que o certo é o que é útil para a pessoa individual ou para a coletividade. A pessoa que segue esse critério moral toma as suas decisões de acordo com a utilidade. Então falta para ela o compromisso, o interesse e a obrigação pessoal com uma causa, que possa não ter uma utilidade. Essa tendência se mistura com o pragmatismo, com o tecnicismo e todos os "códigos" de ética mecanicistas. Para o utilitarista, o bom é aquilo que funciona. Se não funciona, então não é bom.

- Consequencialismo - a quarta tendência que substitui o Tao no arcabouço de valores de uma pessoa é a eficiência das suas decisões, ou seja, que consequências se espera que elas tenham para a pessoa, de preferência consequências de sucesso e eficiência. ${ }^{8}$ Mas um ladrão pode ser muito eficiente em sua técnica de ladroagem, tanto que se enriquece. E, se ele for ainda mais eficiente, ele o fará sem ser pego, ou seja, sem sofrer as consequências que a lei lhe imporia. Nem assim pode ser considerada uma pessoa ética e correta. A pessoa ética se comporta como tal, mesmo que ninguém esteja olhando, coisa inconcebível e ilógica aos adeptos do consequencialismo.

Baseado em "behavior", que significa "comportamento" e nas experiências de estímulo-e-resposta de Pavlov, que serviram de base para as teses de Skinner.

8 A popularidade dessa moral nas pessoas consumistas e materialistas modernas se vê pelo sucesso que fazem os livros que dão receitas para a vida "bem-sucedida" ou de sucesso, particularmente, financeiro. 
E mais uma vez, nos deparamos com a discussão sobre a realidade. Seria ela o que se parece para nós (tal comportamento me parece justo porque ninguém está vendo) ou teria ela um significado vindo de fora, uma parte externa? É em torno da noção de realidade e de confundir o paciente sobre ela que giram noventa por cento das estratégias do diabo veterano de Cartas de um Diabo a seu Aprendiz, de C.S. Lewis, com as suas recomendações e comentários epistolares ao seu sobrinho, diabo de primeira viagem. Parafraseando Lewis, o diabo diz:

E não o deixe usar a lógica nem ficar a sós com livros, nem abraçar a verdadeira ciência, pois todas essas coisas representam o perigo de que o paciente humano se dê conta de que existe uma realidade "lá fora", que lhe permite chegar a conclusões, entrar em comunicação com o autor (por mais distante ou até morto que ele esteja).

Fugir da realidade é a grande especialidade do homem decaído, já que ele não quer admitir o seu estado, e os diabos só o apoiam nisso. Daí a busca pelo controle dessa realidade, que significa poder. Pode-se dizer, de certa forma, que a história da humanidade é a história da criação de formas de controle da natureza, que segundo Lewis, acabará se revertendo em formas de controle da natureza sobre o ser humano. O que parece que ela teima em ignorar é que a natureza sempre lhe irá escapar, surpreendendo a humanidade com as suas "vinganças" pelos excessos cometidos contra ela em nome do tal "controle". E Lewis alerta em A Abolição do Homem que a consequência da teimosia nesse processo é a própria destruição:

O último estágio virá quando, mediante a eugenia, ${ }^{9}$ a manipulação pré-natal e uma educação e propaganda baseadas numa perfeita psicologia aplicada, o Homem alcançar um completo domínio sobre si mesmo. A natureza humana será a última parte da Natureza a se render ante o Homem (...) A batalha estará definitivamente vencida. Mas a pergunta é: quem exatamente a terá vencido? (LEWIS, 2017a, p. 56).

Lewis está falando aqui a partir de uma época em que a eugenia estava em alta. O nazismo, por exemplo, dizia que as pessoas deficientes não tinham o direito de viver e de reproduzir os seus códigos de DNA em meio à humanidade. Elas eram separadas, segregadas, porque os genes delas poderiam contaminar a sociedade. Da mesma forma que os judeus eram perseguidos, as pessoas com qualquer deficiência eram também perseguidas. E o nazismo

9 Trata-se da ciência que estuda o cultivo de condições que tendem a melhorar as qualidades físicas e morais de gerações futuras, especialmente pela genética e controle das características genéticas dos filhos de um casal. 
prega que a evolução é tal que as pessoas mais brancas ou amarelas, arianas ou mongóis, sejam as mais inteligentes, em detrimento das pessoas, negras, mulatas ou latinas. E assim, de forma sutil e aparentemente "científica", instaura-se um Estado totalitário:

Mas os projetistas de homens destes novos tempos estarão armados com os poderes de um Estado onicompetente e uma irresistível tecnologia científica: obteremos finalmente uma raça de manipuladores que poderão, verdadeiramente, esculpir toda a posteridade a seu bel-prazer [...] Os Manipuladores, nesse ponto, estarão em condição de escolher que tipo artificial de Tao irão impor à raça humana, segundo as razões que lhes convierem. (LEWIS, 2017a, p. 26).

Um mundo assim é retratado em Admirável Mundo Novo de Aldous Huxley. O livro prevê como seria o mundo dominado pelo behaviorismo. Seria um mundo artificial, como o que é promovido pelo N.I.C.E., a entidade representante da ciência e tecnologia no terceiro livro da trilogia espacial de C.S. Lewis, Uma Força Medonha. Tudo o que é para ser feito ou deixar de ser feito seria ditado por um cérebro central (ou no caso da trilogia, de uma cabeça separada do corpo, que vive à base de máquinas) todo poderoso, com uma programação que controlaria toda a humanidade. "Eles são os motivadores, os criadores de motivos. Mas de onde é que tiram esses motivos?" (LEWIS, 2005, p. 59), questiona Lewis.

Mais adiante, ele comenta mais sobre esses manipuladores, apresentando a ideia central que está no título do livro:

Não que eles sejam homens maus. Eles não são homens em absoluto. Saindo do Tao, eles caíram no vazio. Nem os objetos do condicionamento serão homens infelizes. Eles não são homens em absoluto: são artefatos. A conquista final do homem mostrou-se a abolição do homem. (LEWIS, 2017a, p. 61).

Essa última frase foi inclusive citada por B.F. Skinner, o fundador do behaviorismo ou comportamentalismo, no livro Beyond Freedom and Dignity [Para Além da Liberdade e Dignidade]. E ele estava criticando a visão de Lewis sobre a abolição do homem, pela ciência, pelo evolucionismo e o comportamentalismo e suas previsões de que essas tendências farão o homem virar máquina e, com isso, viria a destruição da liberdade e de toda a sociedade humana, afirmando que tais coisas simplesmente não existem e não passam de alarmismo inútil e anticientífico. Dai-o título "para além” da liberdade e dignidade, pois elas são meras ilusões para Skinner. Segundo ele o que importa não é o bem e o mal, o homem está acima dessas coisas, mas o controle sobre os instintos, reforçando alguns, que são alegadamente os que levam os seres à evolução, e reprimindo outros, que representam o elemento retrógrado. 
Muitas pessoas acham que o bem e o mal lutam entre si como iguais forças só que o bem acaba vencendo no final, por razões misteriosas ou por alguma "lei do mais forte". Isso se chama maniqueísmo e está muito presente nos filmes de mocinho e bandido e nos desenhos animados de super-heróis. $\mathrm{Na}$ verdade, como os medievais bem o reconheceram, o bem está na origem do mal, sendo que o mal é uma corrupção, uma degradação do bem, como o frio é uma degradação ou falta de calor e a escuridão, falta de luz. Mas o frio não pode substituir o calor, nem a escuridão, expulsar a luz.

Nesse sentido, os manipuladores são o seu próprio mal e destruição. $O$ que faz o totalitário, o ditador, é armar a sua própria destruição, tanto que a maioria deles não sobrevive muito tempo.

No fundo, eles odeiam o que fazem da mesma forma que odeiam a si mesmos. Por isso é que Lewis admite: "Sou propenso a crer que os Manipuladores odiariam os produtos da sua própria manipulação" (LEWIS, 2017a, p. 63).

E é na manipulação que se originam todas as desigualdades humanas, que são destruidoras da paz e da democracia entre os homens.

Portanto, no momento mesmo da vitória do Homem sobre a Natureza, encontramos toda a raça humana sujeita a alguns poucos indivíduos, e estes indivíduos sujeitos àquilo que neles mesmos é puramente "natural" - aos seus impulsos irracionais. A Natureza, livre dos valores, controla os Manipuladores e, por intermédio deles, toda a humanidade. A conquista do Homem sobre a Natureza revela-se, no momento da sua consumação, a conquista da Natureza sobre o Homem. (LEWIS, 2017a, p. 64).

Em outro trecho, Lewis observa que:

Aquilo que chamamos de poder do Homem é, na realidade, um poder que alguns homens possuem, e que por sua vez podem ou não delegar ao resto dos homens. Novamente, no que se refere ao poder do avião ou do rádio, o Homem é tanto o paciente ou o objeto como o possuidor de tal poder, uma vez que ele é o alvo tanto das bombas quanto da propaganda. (LEWIS, 2017a, p. 52).

Aqui Lewis deixa claro porque não é naturalista e não pode concordar com o comportamentalismo, pois ele se origina de uma busca ilegítima e ilusória pelo poder, pelo controle das forças naturais e das pessoas mesmas, que são manipuladas à sua revelia, pelo que se está infringindo a regra universal da liberdade e da dignidade humanas, negadas por Skinner. Nessa mesma esteira, filósofos como Nietzsche defendem a total independência do homem para criar a sua própria vida, valores, história, de maneira egoísta e relativista, mas que no fim, leva à loucura e destruição. 
Ora, essa lei é tão universal que dela falam todos os povos, cristãos ou não. Todos os mitos e lendas se inspiram nela, porque ela se revela a quem indagar a sua realidade e a si mesmo a respeito delas. Trata-se, por assim dizer, de uma revelação universal a todos aqueles que inquirem a totalidade do real com honestidade e abertura de mente e coração.

\section{O que defende o Tao}

Mas o que mais precisamente defende a filosofia antiga oriental ou clássica? Dizíamos que ela defende o chamado "caminho dourado do meio" entre dois extremos: nem tanto ao céu, nem tanto à terra, assumindo uma posição intermediária, equilibrada, moderada.

Confúcio exprimia essa regra única e universal em "Não faça aos outros o que não quer que os outros façam a você". E Jesus usou palavras semelhantes a essas também na Bíblia, mas numa versão mais proativa, positiva: "Faça aos outros o que você gostaria que fizessem a você".

O Tao defende a relação correta entre fins e meios e a atitude correta diante do outro. O antiético acusa o outro de o ter induzido ao erro. Ora, não se pode simplesmente querer justificar um erro por outro erro. Não se pode dizer que se agiu de determinada forma, porque outro o induziu a tanto. Cada um tem responsabilidade por seus atos. Do contrário, estaríamos diante de um regresso infinito de justificações e então, estaria tudo justificado e cairíamos no relativismo.

Não se pode justificar os meios pelos fins ou tomar fins por meios ou vice-versa. Não se pode querer ganhar dinheiro pelo prazer de simplesmente acumular riqueza, como um fim em si mesmo, deve-se ganhar dinheiro como recompensa, como meio de subsistência, de bem-estar e de ajuda ao próximo. Da mesma forma, não se deve usar o desejo das pessoas pela felicidade como meio de ludibriá-las e exercer domínio sobre elas, como faz a propaganda.

Reiteramos: o Tao não é uma consequência, mas um ponto de partida. Então não é uma ética voltada para fazer coisas que, se não forem feitas, terão consequências ruins para a pessoa. O Tao é por onde se começa, de onde se parte, pois se não se parte daí, não se chega a lugar algum ou se chega a um lugar equivocado. Fica-se desnorteado. É uma ética, até certo ponto, muito prática, muito assertiva. ${ }^{10}$

\footnotetext{
10 Trata-se de um conceito amplo, mas que pode ser equiparado à pro atividade e à adoção de uma postura de respeito ao próprio espaço e àquele do outro. Ser assertivo é, diante de uma situação de estresse, não reagir nem de forma agressiva, nem passiva, mas equilibrada.
} 
Trata-se de um fundamento último, basilar, universal, que orienta o certo e o errado em moldes bem abrangentes. Podemos ilustrar isso com o exemplo da geometria. Para se localizar um ponto no espaço, é preciso que esse seja colocado em um sistema cartesiano, ou seja, no interior de dois (na geometria plana; ou três, na espacial) eixos: um horizontal, um vertical (e o terceiro diagonal) que se cruzam no que se convencional chamar de ponto zero. Somente a partir desses grandes pontos referenciais (veja eles não vão ao detalhe da conduta particular em situação determinada) é possível situar um ponto no espaço. Essa é a técnica empregada pelos mapas para a orientação e localização de uma localidade na geografia local.

Mas é preciso que esses referenciais sejam tidos por absolutos e independentes de tempo e espaço para que funcionem. É preciso que sejam estáveis, para que se possa lidar com a instabilidade do tempo-espaço. O mesmo acontece com os valores. A grande maioria deles depende: das circunstâncias, do contexto histórico, geográfico-político, linguístico e tantos outros. Mas há aqueles valores estabelecidos desde a ética clássica (de Aristóteles e que foi assumida por toda a Idade Média) das virtudes cardeais, que não mudam através do tempo, que são milenares:

Nunca houve, e nunca haverá, um juízo de valor radicalmente novo na história do mundo. Tudo aquilo que pretende ser um novo sistema ou (como se diz agora) uma "ideologia" consiste em fragmentos do próprio Tao, arbitrariamente arrancados de seu contexto e então hipertrofiados até a loucura em seu isolamento, mas devendo ainda ao Tao, e somente a ele, a validade que possuem. (LEWIS, 2017, p. 42).

Os valores que o Tao prega, o amor ao próximo e dar a cada um o que lhe é devido (que é o conceito de Justiça, que encabeça as chamadas virtudes cardeais), são milenares. Não são coisas que o homem tão avançado de hoje criou. São valores que a humanidade toda aprendeu com a experiência e a vida, e apregoa desde sempre em sua arte e sua literatura.

\section{Ciência e magia}

Em seguida, Lewis faz uma comparação interessante entre ciência e magia. A magia é a manipulação de certas coisas para você atingir um determinado fim. É conseguir controlar alguma coisa para atingir determinado resultado, manipulando elementos da natureza. A ciência de certa forma também é assim, propondo-se a controlar as variáveis de determinado experimento, para chegar a uma conclusão ou teoria sobre um fenômeno. Só mesmo quando quem determina as leis e aqueles que são controlados por 
elas chegam a um acordo é que pode haver progresso e avanço no processo civilizatório, do contrário, o que ocorre é um domínio de uns sobre os outros. $\mathrm{E}$ esse acordo deve ser regido pela ética e por valores universais. Nas palavras de Lewis, "somente o Tao é capaz de prover uma lei de ação humana comum que possa abarcar legisladores e legislados igualmente" (LEWIS, 2017, p. 69).

A quem, por exemplo, se deve apelar, quando se está diante de um crime contra os direitos humano? Um tribunal internacional? A ONU? Sim, mas será que esses órgãos também não representa um poder que tem interesse em controlar o certo e o errado?

Mais adiante, Lewis conclui:

O grande esforço da bruxaria e o grande esforço científico são irmãos gêmeos: um deles era doente e morreu, o outro era forte e sobreviveu. Mas eram gêmeos. Nasceram do mesmo impulso... Para os sábios da antiguidade, o problema principal era como conformar a alma à realidade, e a solução encontrada foi o conhecimento, a autodisciplina e a virtude. Tanto para a bruxaria quanto para a ciência aplicada, o problema é como subjugar a realidade aos desejos dos homens, e a solução encontrada foi uma técnica. (LEWIS, 2017, p. 72-73).

Além do primado da técnica para o controle da realidade (daí surge a tecnologia), a ciência tem a característica que tentar ir até o princípio primeiro de todas as coisas. Ela quer descobrir as chamadas leis da natureza. Mas qual é a utilidade disso?

Parafraseando Lewis, ele afirma que: "Não há nenhuma utilidade em tentar 'enxergar o que está por trás' dos primeiros princípios”. Ou seja, ele está discutindo aquela mania que o cientificista tem de querer desvendar, tirar os véus, da realidade, como se fosse algum Deus (aliás, a semelhança com o pecado do Éden, não é mera coincidência). Se você "enxergar" o que está "por trás" de todas as coisas acabará por estabelecer um mundo "transparente", sem substância. Por exemplo: o marxismo enxerga por trás da injustiça social a luta de classes; a psicanálise tenta enxergar por trás do comportamento o impulso sexual. Parece que o ser humano da era do cientificismo e da contemporaneidade é totalmente subjetivo, subjetivista. Ele é que determina o que quer enxergar na realidade e o faz de forma determinista.

Essa ideia de que é a impressão dos sentidos na mente que determina a realidade se desdobra em duas convicções: 1 . O que acontece só pode ser levando em conta se for registrado; 2 . Se você ainda não conquistou certo saber, não controlou certa doença, é só uma questão de tempo para o fazer. Para o indivíduo que pensa assim, a ciência vai conquistar todas as coisas, se ela não conquistou é porque não alcançou ainda. Perguntaram a uma criança 
da contemporaneidade o que pensa da morte. Ela disse "ah, é algo ruim que a ciência ainda não resolveu".

A ideia de que a ciência vai chegar à perfeição ou levar a um mundo perfeito é uma ilusão que tem o potencial de se tornar uma religião. E ela diz que não há o concreto, apenas o pensado e percebido. Mas um mundo completamente transparente é um mundo invisível. Por isso é que Lewis diz: "Ver o que está 'por trás' de todas as coisas é o mesmo que não ver nada" (LEWIS, 2017a, p. 77).

Ao invés disso, Lewis nos convida a "ver as coisas como elas são", a "cair na real", não só no sentido de deixar de ter ideias psicodélicas, mas de olhar para além do "aqui e agora", para "além" do real, partindo desse mesmo aqui e agora, ou seja, partindo do concreto.

Por isso, a via do concreto e do real é a via mais importante e segura para uma visão maior, para "abrir os horizontes" da nossa perspectiva limitada para a transcendência. E essa é a perspectiva que o educador que quer "irrigar desertos" deve assumir.

\section{O Tao e a educação}

Mesmo que nunca tenha desenvolvido uma teoria educacional, pode-se extrair das obras de Lewis bases da sua educação: a formação clássica e medieval das Artes Liberais, que envolviam o Trivium (Lógica, Retórica, Gramática) e o Quadrivium (disciplinas curriculares); a teologia e a autobiografia como uma busca pela a alegria; o "batismo" da mente (razão) pela imaginação e a colaboração entre ambas na construção do conhecimento; a crítica contra os "ismos" modernos; e a possibilidade e até a propensão para se aprender, mesmo em tempos de guerra.

E qual a finalidade real da educação? É formar o ser humano no sentido de Bildung (o termo em alemão que significa formação). Essa palavra vem de "Bild" (que significa imagem). Então Bildung é a formação a partir de uma imagem (portanto com uso da imaginação), de um modelo, de um padrão externo. E Bildung é unir razão, emoção e imaginação em torno do ser. Educar não significa nada mais do que isso: $\boldsymbol{e}$ - ducere (colocar para fora o ser). Significa envolver o sujeito em uma integralidade, incluindo a mente, o coração e o espírito.

Nesse sentido, é preciso repensar os currículos, que hoje estão limitados às chamadas "disciplinas", porque a informação está presente em qualquer internet que você a possa acessar. Não é preciso nem professor, nem escola para isso. A função do professor não é transmitir informações. A função dele é de coordenar o aprendizado e mediar a educação. A escola não deve 
ser um lugar de ditadura da maioria, de nivelação por baixo. Ela não deve promover a ideia de que todos têm que estar no mesmo patamar e estar com a mesma média de nota, como prova ou sinal de qualidade. Cada ser é um ser único. A diferença deve existir e a igualdade, ser decorrência dela. A escola e o educador devem lutar contra as gangues, o bullying, e passar a gerar um ambiente de empatia, favorável aos estudos, destacando o prazer de aprender, através do uso da imaginação.

Então, Lewis defendia uma educação integral, também chamada de holística. Educação entendida como Paidéia, um conceito grego e também judaico da educação. Ela abarca o ser humano em sua integralidade, envolvendo mais do que os dois hemisférios do cérebro: envolvendo o corpo todo e a mente toda.

Se a mente é um órgão da verdade, diz Lewis, a imaginação é o órgão do sentido. Uma coisa não vive sem a outra. São as duas asas do anjo. Para uma criança que só recebe informações, ela entra por um ouvido e sai pelo outro. $\mathrm{O}$ conhecimento tem que ter para ela algum peso, algum sentido ou articulação significativa com o cotidiano, se não, ela não aprende. Então Lewis defendia a educação (inclusive a teológica), mediada pela imaginação poética. E trata-se de uma proposta significativa contrária às escolas experimentais (pelas quais ele passou na infância), fomentadoras da autossuficiência, das gangues e do pragmatismo utilitarista e do tecnicismo.

Ele acreditava que a educação tem a priori absolutos. Se não há verdade, não há educação para a verdade. Mas se não existe "a verdade", como é possível existirem "as verdades"? Tem que haver um critério para que as verdades sejam consideradas verdadeiras. Há de haver algum padrão. A educação pressupõe uma lei moral ou natural, o "Tao". Educar, então, é conduzir para um fora, realizar (que é tornar real) potencialidades e complexidades. Somente assim é possível atingir aquela excelência a que se pode chegar, o maximum potentiae, ou ao auge da potencialidade realizada, que foi o termo cunhado por Tomás de Aquino.

\section{O imaginário, o lúdico e a educação}

Em Homo Ludens, Huizinga (1971) já destacava o aspecto inalienável do homem: sua capacidade imagética ou lúdica, do jogo e da festa. O ser humano é um ser que age e reage a partir de imagens, do lúdico. Ele aprende, se revela e se realiza através de sua capacidade imagética, do lúdico, do jogo e mesmo da fé. Lembrando que fé é uma certeza que se tem de coisas que os olhos não enxergam. E é da imaginação que procede a fé. ${ }^{11}$

11 Nesse sentido, não há momento da vida mais imaginativo do que a oração, mas isso daria substrato para outro capítulo. 
Mais que humano, o lúdico é traço divino (imago dei). Por Deus ser criador, nós também somos criadores. O ser humano é um ser análogo ao divino, em plano inferior, em um plano decaído. Educação nesse sentido é um projeto de restauração, que por sua vez, é resultado de uma projeção de Deus no homem, que o mal não teve poder suficiente para desfazer. Assim, a educação se desenvolve de acordo com um projeto (divino) de formação (Bildung), resgate e restauração do ser.

Parafraseando Lewis (2017) em Cristianismo Puro e Simples: "esse mundo é um lugar ocupado pelo inimigo" e nós estamos engajados na missão de subverter esse poder ilegítimo. Nesse sentido, educação é, quer os teóricos o abominem, quer não, uma missão e uma das mais importantes para o futuro da humanidade, pois é uma missão de regeneração e de resgate. ${ }^{12}$ Portanto, a educação deve, sim, ter um compromisso com a razão, mas também com o lúdico, a imaginação, o sentido e a experiência vital.

Mas só imaginação e lúdico não basta. Tem que ser boa imaginação. E para merecer o título de boa, o bem tem que ser assumido e com ele, todos os valores da liberdade e dignidade humanas que se encontram no Tao. Do contrário, se for má imaginação, servirá para o mal. E não adianta impor a bondade às imagens. É preciso extrair a bondade delas, através da interpretação. Trata-se da árdua tarefa (e por ser árdua, muitas vezes é abandonada) de extrair o joio do trigo.

Aquele pai ou mãe que se preocupa com o filho que gosta de Harry Potter, que gosta de Vídeo Games violentos, deve se preocupar sim, mas é em acompanhar o filho, e não proibir simplesmente o filho de assistir, ler ou jogar. Eles devem ensiná-lo a lidar com a sua própria imaginação, a pegar aquelas imagens e interpretar da forma correta, tirando os valores de coragem, de lealdade, de amizade, que todo jogo tem. Ele deve focar nestes aspectos positivos, não nos negativos.

Nesse sentido, todos os textos, especialmente os imaginativos, são uma pequena encarnação de valores que para nós parecem abstratos. E tal encarnação se dá sem dar aviso. É como o Espírito que sopra e não se sabe quando e onde vai se revelar. A criança, de forma análoga, também não escolhe o lugar onde vai aprender, ela aprende simplesmente. Ela não pede licença para aprender, o que sempre envolve uma superação, um salto para algum lugar que transcende o nível anterior de conhecimento do educando. Em última instância, essa superação alcança até o próprio Criador.

\footnotetext{
12 Isso lembra novamente a ordem de Lewis em $A$ abolição... de "irrigar desertos" e não "derrubar árvores".
} 
E o mundo está cheio de sinais e imagens de Deus. Um verdadeiro campo minado para Screwtape. ${ }^{13}$ Mas a literatura é mais concentrada em termos de sinais. Deus também não pede licença para se manifestar. Ele escolheu se revelar na natureza, no Verbo, Logos encarnado, e, de forma indireta, nas artes e nos textos, orais ou escritos. Tudo que é bom, inclusive esteticamente, remete a Deus. Parafraseando Simone Weil, "o Belo é a prova experimental de que a encarnação é possível".

A literatura é a encarnação mais contundente do Criador. Tanto que Ele escolheu se revelar através de um livro. E é por isso também que o livro é o meio educacional por excelência. Principalmente aquele que envolve a imaginação.

E como educar através da literatura imaginativa? Primeiro, sendo um bom leitor e bom contador de histórias, que usa todo tipo de imagem. Isso significa saber interpretar da forma correta. É preciso saber usar recursos imagéticos como mediadores para a compreensão de níveis mais profundos da realidade circundantes, fazer boas perguntas, ser um mediador e um facilitador. É preciso indicar boa literatura, bons filmes, que valorizam os aspectos positivos da vida humana e suas manifestações imagéticas, usar a imaginação menos para veicular conteúdos (pelo que ela fica asfixiada) do que para a fruição e contemplação. Por exemplo, você não vai perguntar qual a moral da história no começo da história. Deixa que a criança interprete ela mesma, que ela mesma chegue a uma moral. E deve aproveitar a oportunidade para promover o discernimento e a sabedoria, lembrando que a sabedoria vem de saber, de sabor, de Sophia, que é o nome grego da sabedoria. É nesse sentido que educar "não é derrubar florestas, mas irrigar desertos". E a educação atual está mais do que precisando dessa irrigação.

\section{Considerações finais}

Ao final deste artigo, resta-nos perguntar: Quais as implicações educacionais de $A$ Abolição do Homem?

São elas: que devemos combater a situação desértica da educação, cheia de sentimentos ilusórios, irrigando-a com sentimentos verdadeiros. Parafraseando Lewis novamente, que "a defesa adequada contra os falsos sentimentos é inculcar os sentimentos corretos". Ao sufocar a sensibilidade dos nossos alunos, entupindo-os com informações, apenas conseguiremos transformá-los em presas mais fáceis para o ataque do propagandista.

13 Nome original do Diabo em Cartas de um Diabo a Seu Aprendiz, de C.S. Lewis. 
É preciso desenvolver um trabalho com uso da imaginação e da literatura para fomentar uma visão mais equilibrada da vida e do homem, em um mundo racionalista, materialista e cientificista. Assim, poderemos fomentar a regeneração do ser do educando para que ele se torne o que ele realmente é, parafraseando Píndaro: "Torna-te o que tu és". Destarte, poderemos ainda seguir uma visão do que o educando deve ser, visão inspirada em valores universais do Tao, orientando o aprendizado esperançosamente para ela.

Só assim impediremos a derrubada de árvores na educação e sua devassidão e, pelo contrário, faremos o deserto verdejar.

\section{Referências bibliográficas}

HEIDEGGER, Martin. Sobre a essência do fundamento; A determinação do Ser do Ente segundo Leibniz; Hegel e os gregos. Trad. Ernildo Stein. São Paulo: Duas Cidades, 1971.

HUIZINGA, Johan. Homo ludens, o jogo como elemento da cultura. Trad. João Paulo Monteiro e Newton Cunha. São Paulo: Perspectiva; Edusp, 1971.

OTTO, Rudolf. O sagrado: aspectos irracionais na noção do divino e sua relação com o racional. Trad. Walter O. Schlupp. São Leopoldo; Petrópolis: Sinodal; Vozes, 2007.

LEWIS, C.S. A Abolição do Homem. Trad. Gabriele Greggersen. São Paulo: Thomas Nelson, 2017 a.

Audiobook - Disponível em: <http://www.youtube.com/watch?v=VTum5vajIXg\&list=PL 96511B9130D52FBB>. [Acesso em: 24 de junho de 2014].

LEWIS, C.S. Cartas de um diabo a seu aprendiz. Trad. Gabriele Greggersen. São Paulo: Thomas Nelson, 2017b.

LEWIS, C.S. Cristianismo puro e simples. Trad. Gabriele Greggersen. São Paulo: Thomas Nelson, 2017c.

LEWIS, C.S. Uma força medonha. São Paulo: Martins Fontes, 2005.

MACHADO, Ana Maria. Como e por que ler os clássicos universais. Rio de Janeiro: Objetiva, 2002.

SARTRE, J.P. A imaginação. São Paulo: Difusão Europeia do Livro, 1987.

Submetido em: 6-11-2020

Aceito em: 9-12-2020 